\title{
ATP Synthase Subunit Beta, Mitochondrial
}

National Cancer Institute

\section{Source}

National Cancer Institute. ATP Synthase Subunit Beta, Mitochondrial. NCI Thesaurus. Code C118527.

ATP synthase subunit beta, mitochondrial ( $529 \mathrm{aa}, ~ 57 \mathrm{kDa}$ ) is encoded by the human ATP5F1B gene. This protein plays a role in ATP synthesis, hydrogen ion exchange and oxidative phosphorylation. 